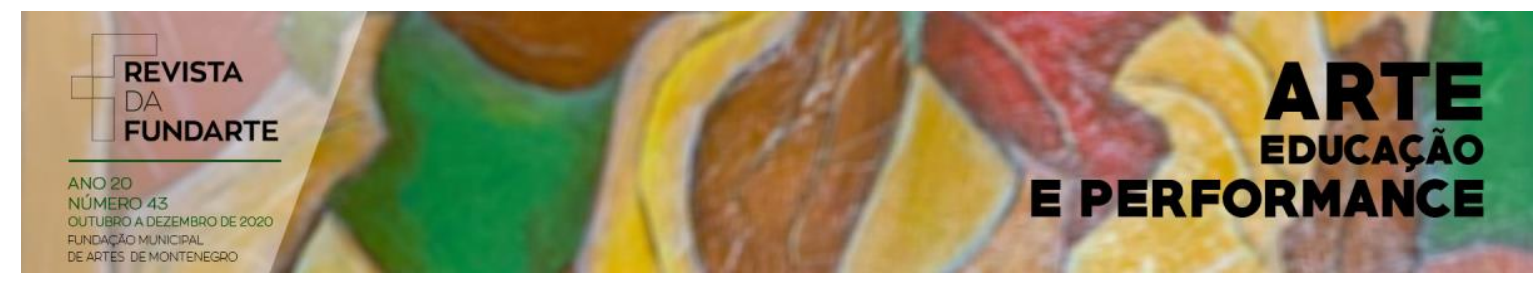

\title{
A CONSTRUÇÃO DO CORPO DOCE DA BAILARINA DA CAIXINHA DE MÚSICA
}

\author{
Daniela Grieco Nascimento e Silva \\ Marcia Gonzalez Feijó \\ DOI: http://dx.doi.org/10.19179/2F2319-0868/2F819
}

SILVA, Daniela Grieco Nascimento e; FEIJÓ, Marcia Gonzalez. A construção do corpo doce da bailarina da caixinha de música. Revista da FUNDARTE. Montenegro, p.01-21, ano 20, no 43, outubro/dezembro de 2020.

Disponível em: http://.seer.fundarte.rs.gov.br/index.php/revistadafundarte/index $>20$ de dezembro de 2020. 


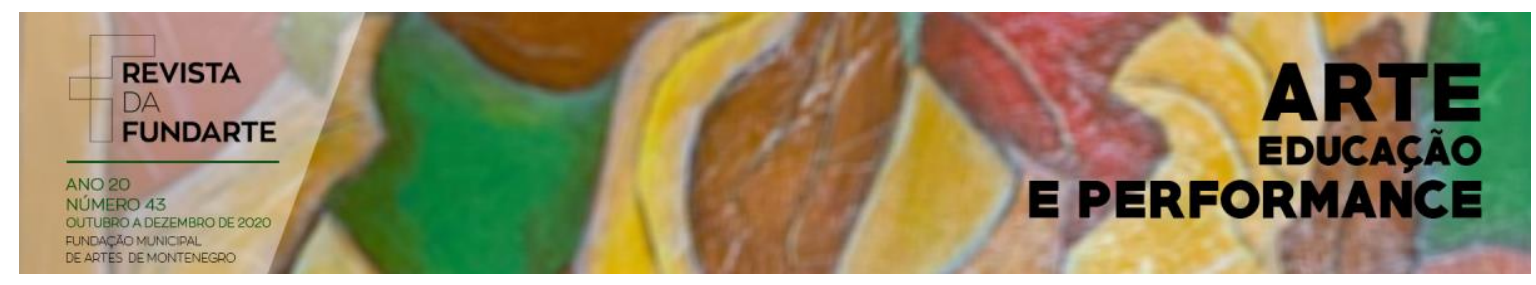

\title{
A CONSTRUÇÃO DO CORPO DOCE DA BAILARINA DA CAIXINHA DE MÚSICA
}

\author{
Daniela Grieco Nascimento e Silva \\ Marcia Gonzalez Feijó 2
}

\begin{abstract}
Resumo: Este artigo, por meio de uma revisão bibliográfica, objetiva refletir sobre a construção do corpo da bailarina clássica. Como as mulheres predominam na prática do balé seu corpo foi representado por meio das relações de poder estabelecidas pela sociedade e pela cultura. Foi construído um corpo doce para a bailarina onde são inscritos os discursos hegemônicos masculinos em relação à feminilidade, criando a figura da bailarina da caixinha de música, símbolo de beleza, graça, leveza, pureza, submissão. Mas novas formas de relações de poder e saber estão sendo tecidas e já começam a rachar velhos paradigmas em relação às mulheres, possibilitando maior igualdade entre os gêneros e que estes reflitam no mundo do balé.
\end{abstract}

Palavras Chaves: Balé clássico; Corpo Doce; Bailarina da Caixinha de Música.

\section{THE CONSTRUCTION OF THE SWEET BODY OF THE DANCER OF THE MUSIC BOX}

Abstract:This article, through a bibliographic review, aims to reflect on the construction of the body of the classical dancer. As women predominate in the practice of ballet, their body was represented through the power relations established by society and culture. A sweet body for the dancer was built

\footnotetext{
${ }^{1}$ Pós Doutoranda em Gerontologia (UFSM), Doutora em Educação - Linha de Pesquisa Educação e Artes - na Universidade Federal de Santa Maria (UFSM), graduada em Pedagogia pelo Centro Universitário Franciscano, Especialista em Psicopedagogia - Abordagem Clínica e Institucional pelo Centro Universitário Franciscano, Mestre em Educação - Ênfase na Linha de Pesquisa Educação, Cultura e Ação Coletiva - pelo Centro Universitário La Salle. Possui formação em balé pela Escola de Ballet Ivone Freire. Membro do Grupo de Pesquisa em Arte, Cultura e Educação - GEPAEC - UFSM, e do Grupo de Estudos em Educação, Arte e Cultura (GEEDAC) - UFSM. Atualmente é diretora artística, coreógrafa e professora de balé na ONG Royale Escola de Dança e Integração Social, em Santa Maria - RS. Tem experiências nas áreas de Educação e Arte, com ênfase em Educação das Artes, atuando principalmente nos seguintes temas: dança, gênero, estudos feministas.

2 Professora na Universidade Federal de Santa Maria (CEFD) nos cursos de Dança Licenciatura; Cursos de Bacharelado e Licenciado em Educação Física. Graduada em Licenciatura Plena em Educação Física (UFSM). Doutorado em Educação, na linha Educação e Arte ( UFSM). Mestrado em Ciência do Movimento Humano pela Universidade Federal de Santa Maria.Formação em Dança para Bailarino de corpo de Baile com vários cursos complementares nesta área. Certificada pela Polestar Certiefeld Pratciitioner of Pilates Studio, como instrutora. Atua nas seguintes temáticas: Dança; Educação Somática;Terapias do corpo; Processos de criação em dança; com ênfase nos estudos do corpo, arte, cultura e qualidade de vida.
}

SILVA, Daniela Grieco Nascimento e; FEIJÓ, Marcia Gonzalez. A construção do corpo doce da bailarina da caixinha de música. Revista da FUNDARTE. Montenegro, p.01-21, ano 20, no 43, outubro/dezembro de 2020.

Disponível em: http://.seer.fundarte.rs.gov.br/index.php/revistadafundarte/index $>20$ de dezembro de 2020. 


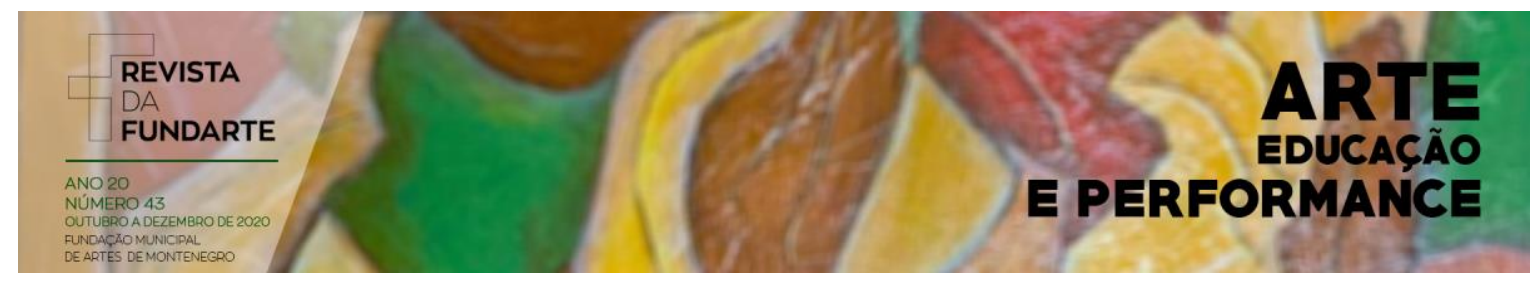

where male hegemonic speeches regarding femininity are inscribed, creating the figure of the dancer in the music box, symbol of beauty, grace, lightness, purity, submission. But new forms of relations of power and knowledge are being woven and are beginning to break old paradigms in relation to women, allowing greater equality between genders and that these reflect in the world of ballet.

Keywords: Classical ballet; Sweet Body; Ballerina from the Music Box.

\section{Introdução}

O propósito deste artigo é refletir, por meio de uma revisão bibliográfica, sobre a construção do corpo da bailarina clássica. Partindo do pressuposto que as mulheres são predominantes na prática do balé, cabe salientar que seus corpos foram representados por meio das relações de poder estabelecidas pela sociedade e pela cultura (Beauvoir, 1980a). Foi construído um padrão corporal para a bailarina clássica onde são inscritos os discursos hegemônicos masculinos em relação à feminilidade, criando o mito do eterno feminino e edificando uma imagem da bailarina associada às mulheres do período romântico criando, assim, a figura bucólica da bailarina da caixinha de música.

Assim, para dar conta do objetivo proposto, o trabalho foi estruturado a partir de três momentos. O primeiro apresenta uma reflexão sobre a imagem feminina no balé. O segundo descreve sobre os processos de disciplinarização dos corpos femininos que geraram a figura da bailarina da caixinha de música. E o terceiro momento tece algumas reflexões sobre a temática proposta.

\section{A imagem feminina no balé}

A imagem da bailarina delicada, diáfana, vestida com tuttu cor de rosa, rodopiando delicadamente ao som de uma música suave diante dos espelhos de uma caixinha de música, povoa o sonho de milhares de meninas ao redor do mundo. Ligada ao mundo da imaginação e da fantasia por realizar proezas corporais

SILVA, Daniela Grieco Nascimento e; FEIJÓ, Marcia Gonzalez. A construção do corpo doce da bailarina da caixinha de música. Revista da FUNDARTE. Montenegro, p.01-21, ano 20, ํㅡ 43, outubro/dezembro de 2020.

Disponível em: http://.seer.fundarte.rs.gov.br/index.php/revistadafundarte/index $>20$ de dezembro de 2020. 


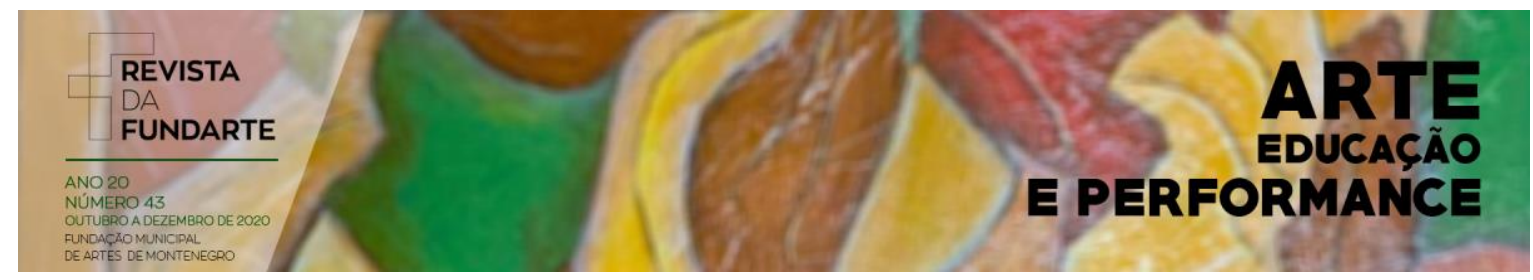

diferenciadas daqueles que não dançam, a imagem da bailarina foi construída por meio de diversos marcadores sociais, culturais e políticos, que escreveram em seu corpo símbolos desta representação feminina, explicitada pela postura, gestos, movimentos, roupas e comportamentos.

Voltando à imagem da bailarina da caixinha de música pode-se perceber que é construído um corpo doce para a bailarina. Um corpo obediente, disciplinado, bonito, gerador de satisfação para si e para os outros, mas condenado a repetir eternamente os mesmos movimentos diante dos espelhos da vida.

O corpo do brinquedo propaga suas ressonâncias no mundo real. Todos os anos, milhões de meninas são levadas por mães ansiosas a escolas de balé a fim de desenvolver "boa postura", "graça", "leveza", "delicadeza", "beleza" e, quem sabe um dia, brilhar num palco. A inserção no mundo do balé quase sempre é realizada pela mãe, como mais um aprendizado do universo feminino, onde qualidades "doces" como as anteriormente citadas, são incentivadas nas meninas desde cedo.

Assim como os meninos são incentivados a práticas corporais culturalmente associadas ao mundo masculino - futebol, lutas, basquete, etc. - e que exigem atributos como força física, coragem, audácia, persistência, liderança. As meninas são levadas a realizar atividades próximas ao universo materno, onde aprenderão a se construir como mulheres e serão ensinadas a desenvolver características consideradas femininas - meiguice, delicadeza, recato, submissão. O balé, nascido nas cortes renascentistas e simbolizado pelas figuras das bailarinas do período romântico, encaixa-se perfeitamente no ideal de feminilidade da sociedade patriarcal (HOMANS, 2010).

O patriarcalismo, de acordo com Simone de Beauvoir (1980a), não nasceu juntamente com os sujeitos, mas foi construído socialmente e culturalmente com a evolução humana. No início da história da humanidade, as primeiras sociedades humanas eram coletivas, tribais, nômades e matrilineares, sendo organizadas em torno da figura da mãe, a partir da descendência feminina, uma vez que se

SILVA, Daniela Grieco Nascimento e; FEIJÓ, Marcia Gonzalez. A construção do corpo doce da bailarina da caixinha de música. Revista da FUNDARTE. Montenegro, p.01-21, ano 20, no 43, outubro/dezembro de 2020.

Disponível em: http://.seer.fundarte.rs.gov.br/index.php/revistadafundarte/index> 20 de dezembro de 2020. 


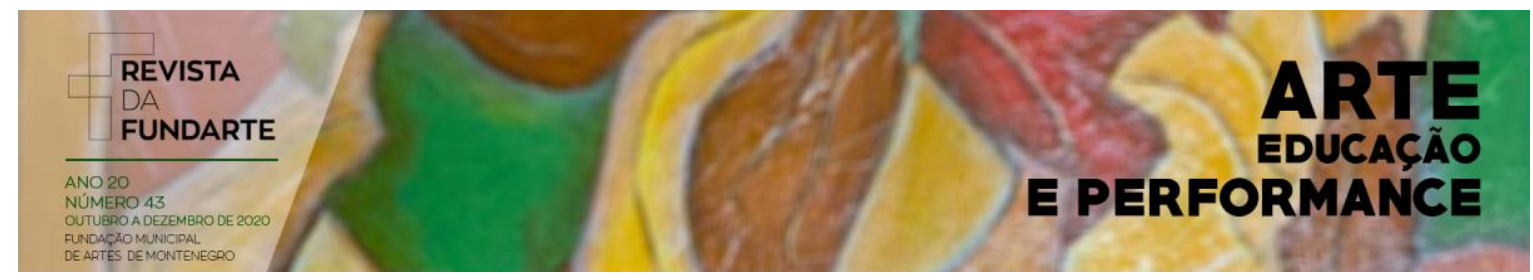

desconhecia o papel masculino na reprodução. Os papéis sexuais e sociais de homens e mulheres não eram organizados de forma rígida, a monogamia não existia e as relações sociais eram igualitárias.

Com a descoberta da agricultura, da caça e do domínio sobre o fogo, as comunidades passaram a se fixar em um território. As funções sociais começaram a ser divididas de acordo com os atributos físicos: aos homens cabia caçar e as mulheres ficariam responsáveis pelo cultivo da terra e pelos cuidados das crianças. Com o conhecimento do papel masculino na reprodução e o estabelecimento da propriedade privada, as relações passaram a ser predominantemente monogâmicas, a fim de garantir o direito de herança aos filhos legítimos.

Instituindo-se, de acordo com Simone de Beauvoir (1980a), a família monogâmica e a divisão sexual e social do trabalho entre os homens e as mulheres, instaura-se o patriarcado, uma nova ordem social centrada na descendência patrilinear e no controle dos homens sobre as mulheres. O patriarcado não designa o poder do pai, mas o poder do masculino enquanto categoria social, sendo uma forma de organização social na qual as relações são regidas por dois princípios fundamentais: as mulheres são hierarquicamente subordinadas aos homens e os jovens são hierarquicamente subordinados aos homens mais velhos.

A supremacia masculina ditada pelos valores do patriarcado atribuiu um maior valor às atividades masculinas em detrimento das atividades femininas; legitimou o controle da sexualidade, dos corpos e da autonomia femininas; estabeleceu papéis sexuais e sociais nos quais o masculino tem vantagens e prerrogativas. Assim, a sociedade é patriarcal em sua totalidade, pois as mulheres são submetidas aos homens, tanto na esfera privada quanto na esfera pública. Embora o patriarcado tenha alterado algumas configurações ao longo dos anos, manteve em sua essência premissas do seu pensamento original.

A dominação masculina exercida pelo patriarcado não corresponde a um imaginário ou a uma ideologia, mas a um sistema performativo e simbólico que por

SILVA, Daniela Grieco Nascimento e; FEIJÓ, Marcia Gonzalez. A construção do corpo doce da bailarina da caixinha de música. Revista da FUNDARTE. Montenegro, p.01-21, ano 20, nํㅜ 43, outubro/dezembro de 2020.

Disponível em: http://.seer.fundarte.rs.gov.br/index.php/revistadafundarte/index> 20 de dezembro de 2020. 


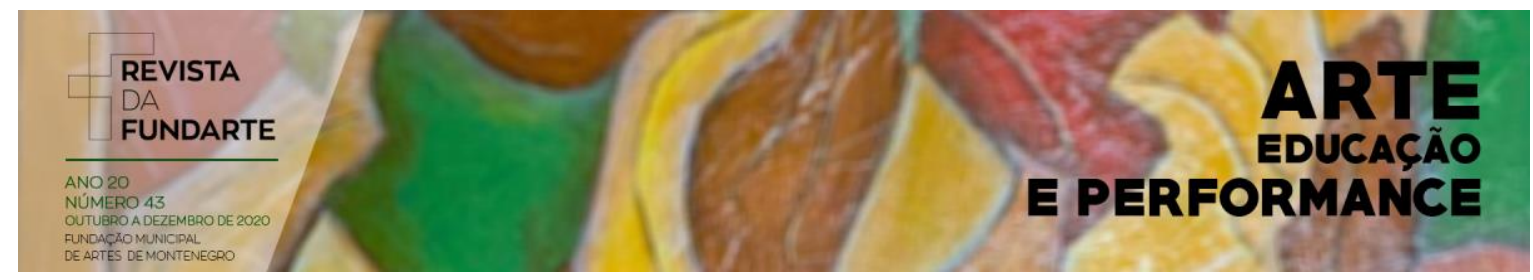

meio do discurso, é inscrito nos corpos dos sujeitos, gerando comportamentos, posturas e ações condizentes com o pensamento dominante.

Ocorre uma verdadeira ação pedagógica sobre os sujeitos, que reitera continuamente nos corpos biológicos os marcadores sociais e culturais relativos às identidades e aos papéis de gênero, reforçando atos, posturas, comportamentos e rotinas condizentes com o desejado pelo sistema patriarcal. Assim, o discurso social e cultural ensina às crianças como ser homem ou mulher, fortalecendo a visão de mundo patriarcal sobre a masculinidade e a feminilidade. Pierre Bourdieu (2015) considera a dominação masculina como uma violência simbólica sobre as mulheres que, de maneira doce e praticamente invisível, toma seus corpos e consciências, fazendo-as totalmente submissas ao poder patriarcal.

Controlar o corpo feminino é uma maneira de sujeição das mulheres, pois no momento em que o poder masculino define o corpo da mulher, ela irá se produzir de acordo com tais representações. Historicamente associada ao pecado pela religião cristã, a mulher foi sempre representada como possuidora de um poder perigoso associado a sua sexualidade. Assim, o corpo da mulher foi dissecado e analisado pelo discurso da ciência, produzindo um saber que a inscreveu como diferente e inferior ao homem, sendo por isso relegada ao mundo privado, onde seria controlada, tendo a função de gerar e criar filhos.

Para Michel Foucault (2014) ocorreu uma articulação do corpo feminino com o corpo social (regulação da fecundidade feminina como mantenedora e asseguradora da população), com o espaço familiar (o corpo feminino mantém, alimenta, nutre, regula a estrutura familiar) e com a vida das crianças (o corpo feminino não é apenas aquele que cuida, mas é também responsável por passar os códigos morais e éticos da sociedade para a criança). Construiu-se uma imagem negativa da mulher. Fechada e controlada no mundo privado, seu corpo foi enlaçado pelo discurso médico e concebido como uma patologia por ser considerado frágil e sensível, dependendo eternamente do cuidado e da proteção masculina.

SILVA, Daniela Grieco Nascimento e; FElJÓ, Marcia Gonzalez. A construção do corpo doce da bailarina da caixinha de música. Revista da FUNDARTE. Montenegro, p.01-21, ano 20, nํ43, outubro/dezembro de 2020.

Disponível em: http://.seer.fundarte.rs.gov.br/index.php/revistadafundarte/index> 20 de dezembro de 2020. 


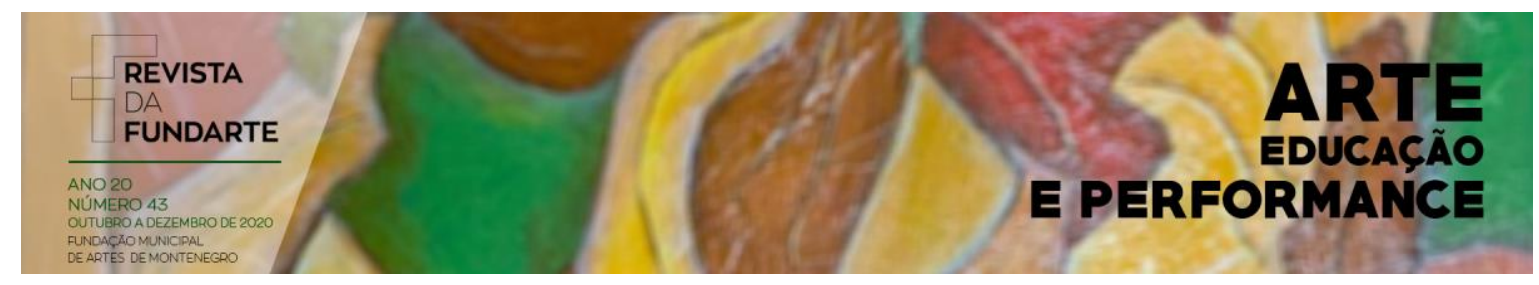

Simone de Beauvoir (1980b) demonstra como as meninas, desde cedo, na relação lúdica com suas bonecas e ouvindo/lendo contos infantis, são incentivadas a construir uma imagem de seu corpo que estabelece ligação entre beleza e feminilidade, fazendo do espelho um medidor dos atributos que deseja ver e ouvir sobre si mesma.

Através de cumprimentos e censuras, de imagens e de palavras, ela descobre o sentido das palavras 'bonita' e 'feia'; sabe, desde logo, que para agradar é preciso ser 'bonita como uma imagem'; ela procura assemelharse a uma imagem, fantasia-se, olha-se no espelho, compara-se às princesas e às fadas dos contos. (BEAUVOIR, 1980b, p. 25).

As representações do feminino incidem subliminarmente sobre as meninas, fazendo-as introjetar as qualidades e valores associados à feminilidade predominante em sua cultura: beleza, doçura, meiguice, submissão, recato, importância da maternidade. Estas são legadas por meio de práticas rotineiras e comuns, especialmente pelas duas maiores referências na vida da criança: a família e a escola. São as palavras, os gestos e os olhares das pessoas que circulam principalmente, por essas duas instâncias que ajudarão a construir a imagem de corpo, estabelecendo a construção da identidade e dos papéis de gênero que serão seguidos pela criança.

A representação social do próprio corpo é, assim, obtida através da aplicação de uma taxonomia social, cujo princípio é idêntico aos dos corpos aos quais se aplica. Assim, o olhar não é apenas simples poder universal e abstrato de objetivação, como supõe Satre; é um poder simbólico cuja eficácia depende da posição relativa daquele que percebe e daquele que é percebido, e do grau em que os esquemas de percepção e de apreciação postos em ação são conhecidos e reconhecidos por aquele a quem se aplicam. (BOURDIEU, 2015, p. 80-81).

A escolha pela prática do balé para as meninas é um modo de reforçar a aquisição de atributos femininos, pois desde a exaltação das imagens das bailarinas

SILVA, Daniela Grieco Nascimento e; FEIJÓ, Marcia Gonzalez. A construção do corpo doce da bailarina da caixinha de música. Revista da FUNDARTE. Montenegro, p.01-21, ano 20, nำ 43, outubro/dezembro de 2020.

Disponível em: http://.seer.fundarte.rs.gov.br/index.php/revistadafundarte/index> 20 de dezembro de 2020. 


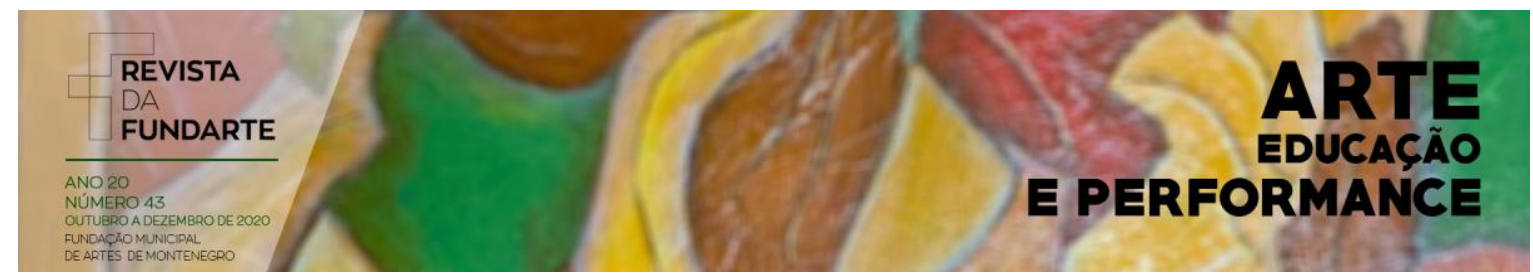

do período romântico, a dança clássica é concebida como uma arte que enaltece e reforça a feminilidade socialmente desejada.

Desde os seus primórdios, a dança clássica mantém regras preestabelecidas para os corpos, definindo de maneira explícita os papéis de gênero pretendidos em sua prática. Aos corpos masculinos são atribuídos valores como força e virilidade, sendo capazes de transportar e deslocar o corpo feminino pelo espaço. Já os corpos femininos tornam-se expressão máxima da feminilidade socialmente e culturalmente desejada. Jogos de poderes atravessam os corpos, tornando o balé um dispositivo de poder.

Incorporado aos demais dispositivos do patriarcalismo, inicialmente a dança associou a imagem da bailarina à prostituição, pois a exposição do corpo feminino nos movimentos da dança realçava a sensualidade e o erotismo, o que era condenado pelo cristianismo (HANNA, 1999).

Durante toda a Idade Média, a moral cristã concebeu o corpo como algo desprezível e vil e cujos desejos e anseios precisavam ser severamente reprimidos a fim de que os sujeitos pudessem elevar 0 espírito sob a matéria. Consequentemente, a dança não era vista com bons olhos pelos detentores do poder, embora algumas manifestações populares fossem toleradas, fazendo com que a Igreja procurasse trazer muitas danças para o culto, recriando-as segundo a visão cristã.

Com o advento do Renascimento, o balé nas cortes européias foi predominantemente desenvolvido por homens que, muitas vezes, executavam papéis femininos travestidos, pois de acordo com a moral da época, as mulheres não deviam se exibir publicamente.

Ocorreram, na Europa, dois movimentos que desencadearam profundas mudanças na sociedade, na política, na cultura e na economia, propiciando às mulheres que, pouco a pouco, pudessem assumir o protagonismo na dança: a

SILVA, Daniela Grieco Nascimento e; FEIJÓ, Marcia Gonzalez. A construção do corpo doce da bailarina da caixinha de música. Revista da FUNDARTE. Montenegro, p.01-21, ano 20, ำ 43, outubro/dezembro de 2020.

Disponível em: http://.seer.fundarte.rs.gov.br/index.php/revistadafundarte/index> 20 de dezembro de 2020. 


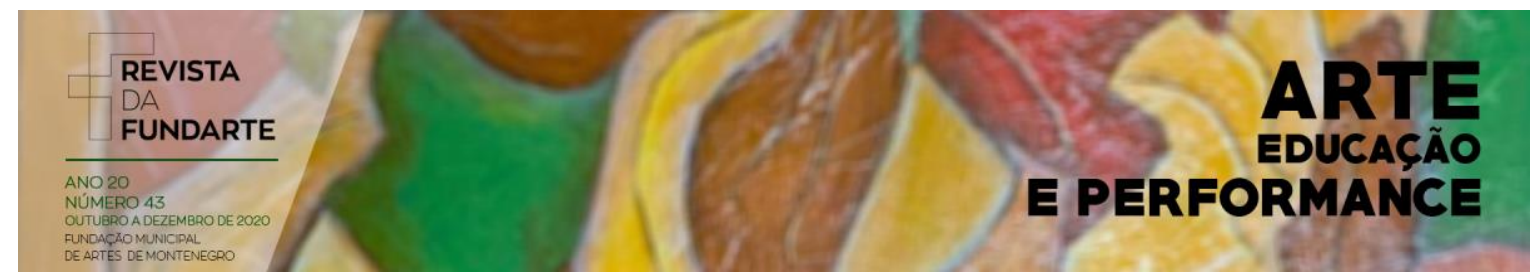

Revolução Francesa, no século XVIII; e a Revolução Industrial, no século XIX. Ambos movimentos trouxeram uma nova visão sobre o corpo humano.

Judith Hanna (1999) salienta que o corpo, já envolvido com o pecado e julgado inimigo da vida espiritual, tornou-se 0 antagonista da produtividade econômica. Como a burguesia francesa em ascensão, atribuiu parte do colapso da monarquia à frouxidão moral, convertendo o corpo, até ali visto como instrumento de prazer, em instrumento de produção. Desse modo, a classe média podia cuidar de seu poder. Autocontrole significava controle do corpo e mais adiante, controle das pessoas que se importassem com o corpo. Consequentemente, a profissão da dança recebeu baixa remuneração financeira e pouco interesse pela carreira por parte dos homens que dominavam a cultura. Muitos homens renunciaram a profissão de bailarino, abrindo espaço para as mulheres.

Mas não foram as burguesas que adentraram nos palcos dos teatros da Europa, pois os princípios morais do período pregavam que as "mulheres de família" deveriam dedicar-se ao lar e aos filhos, não devendo jamais exercer atividades fora do mundo privado, mantendo o recato, a submissão e a discrição. $O$ trabalho braçal, conforme Michelle Perrot (2005), começou a ser relacionado à incapacidade intelectual, sendo normalmente desenvolvido pelas camadas populares. Deste modo, as mulheres das classes sociais mais baixas, que necessitavam trabalhar, eram associadas à imagens de degradação moral e, consequentemente, de prostituição.

Em virtude disso, as bailarinas da Ópera de Paris sofreram forte discriminação social, sendo "julgadas como parte do demi-monde, ou dos escalões da prostituição. A expressão 'garota de balé' tinha uma conotação negativa até metade do século XX e, em alguns lugares, ainda tem" (HANNA, 1999, p. 186).

As jovens bailarinas tornaram-se uma fonte de excitação, pois a exibição do corpo no balé atraía homens ricos, que se deslumbravam com as jovens e belas bailarinas, para a Ópera de Paris. Para uma bailarina tornar-se amante de um

SILVA, Daniela Grieco Nascimento e; FEIJÓ, Marcia Gonzalez. A construção do corpo doce da bailarina da caixinha de música. Revista da FUNDARTE. Montenegro, p.01-21, ano 20, no 43, outubro/dezembro de 2020.

Disponível em: http://.seer.fundarte.rs.gov.br/index.php/revistadafundarte/index> 20 de dezembro de 2020. 


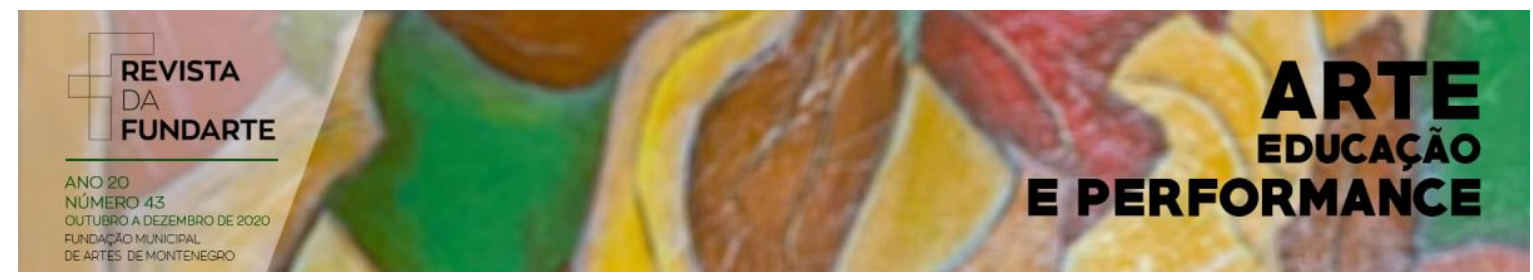

homem rico era uma opção de deixar o palco e obter uma vida confortável. Até a metade do século XX, muitas bailarinas proviam geralmente das classes populares. Para uma menina atraente, tornar-se bailarina da Ópera de Paris era um caminho de mobilidade social. Bailarinas talentosas, que conquistavam o aplauso, a atenção, o galanteio e o compromisso de admiradores ricos eram invejadas pelas outras mulheres, pois conseguiam independência pessoal e financeira, embora sofressem preconceitos da sociedade.

\begin{abstract}
Assim, a posição social das mulheres da Ópera de Paris não as tornava necessariamente mais livres e seguras, mas parecia dar-Ihes uma certa (e às vezes imprudente) coragem. Essas mulheres tinham menos a perder $\mathrm{e}$ muito mais a ganhar saindo da linha ou conquistando notoriedade, sexual ou outra [...] Mas graças a elas, a maneira como a bailarina se deslocava entre a arte e um demi-monde decadente tornou-se tema dominante na história do ballet, e a reputação de uma bailarina muitas vezes dependia tanto da sua conduta pessoal como dos seus méritos artísticos. $E$ não é por acaso que muitos dos artistas mais ousados do ballet nos séculos XVIII e XVI foram mulheres. Sallé e Camargo estabeleceram o modelo: de forma calculada, usaram o gosto da época pelo erotismo, teatro popular e sentimentalismo para orientar o estilo nobre francês numa direção distintivamente feminina, alargando os perímetros da arte e abrindo caminho a desenvolvimentos futuros. (HOMANS, 2010, p. 96-97).
\end{abstract}

Embora muitas bailarinas tenham exaltado o erotismo e a sensualidade feminina no palco, a imagem predominante da bailarina clássica está associada às imagens das bailarinas do período romântico, que exaltaram uma mulher de sonho, uma figura idealizada de mulher, que correspondia ao ideal de feminilidade da época.

Durante o Romantismo, a figura feminina tornou-se fonte de inspiração para poetas, escritores, músicos, pintores e coreógrafos, que a representaram como um caráter puro e majestoso, chegando até a atribuir-Ihe características próprias da natureza, como a índia Iracema da obra homônima de José de Alencar. A virgindade e a sensualidade femininas eram bastante valorizadas nas obras românticas, pois na maioria das produções da época, a mulher é representada como uma heroína

SILVA, Daniela Grieco Nascimento e; FEIJÓ, Marcia Gonzalez. A construção do corpo doce da bailarina da caixinha de música. Revista da FUNDARTE. Montenegro, p.01-21, ano 20, no 43, outubro/dezembro de 2020.

Disponível em: http://.seer.fundarte.rs.gov.br/index.php/revistadafundarte/index> 20 de dezembro de 2020. 


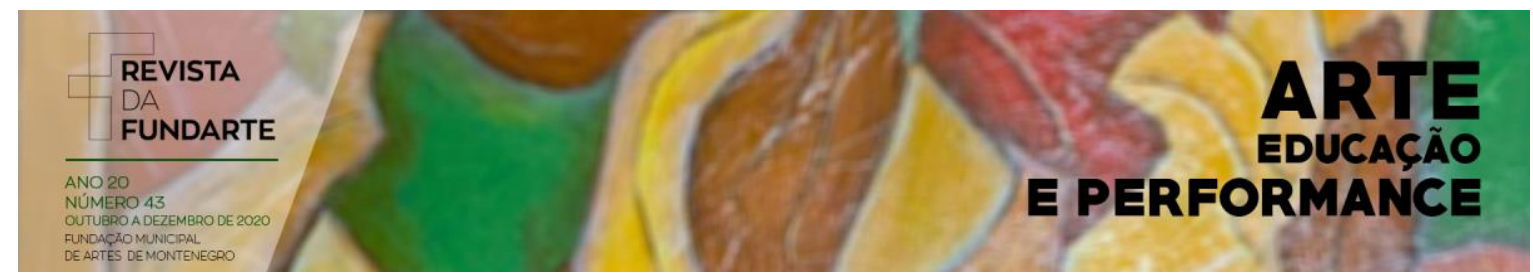

virgem, ingênua, bela e frágil, que deveria ser salva e amada por um nobre cavalheiro. As mulheres que correspondiam ao ideal de feminilidade hegemônico eram exaltadas; já aquelas mulheres que transgrediam as normas, eram apresentadas como cruéis e vingativas feiticeiras, sendo sempre castigadas nos finais das obras, que expressavam um forte caráter moral. Cabe ressaltar que os códigos morais expressavam uma moral viril que era pensada, escrita e exercida pelos homens, onde as mulheres eram concebidas como objetos.

\begin{abstract}
Em geral os papéis de mulher do balé romântico não retratavam mulheres independentes, mas impalpáveis e indefiníveis sílfides ou terrosas e lúbricas camponesas, embora não escravas para o deleite masculino. Havia também as eróticas e macabras Willis, fantasmas vingativos de mulheres traídas que morreram não desposadas; elas condenavam os homens infiéis a dançar até a morte. Talvez o papel da sílfide simbolizasse a idealização da mulher como 'senhora' - compensação para a perda, das mulheres de classe média, de um papel econômico decisivo na família, com o início da revolução industrial. (HANNA, 1999, p. 188).
\end{abstract}

Os principais balés de repertório do período romântico, La Sylphide e Giselle, realçavam as figuras femininas como símbolos máximos da feminilidade romântica que, de certa maneira, se tornou a imagem da bailarina. A primeira representação dessa imagem foi a bailarina italiana Marie Taglioni, intérprete da Sílfide, personagem criada por Adolphe Nourrit e Philippo Taglioni, mostrando uma mulher de sonho que pairava entre o mundo humano e o mundo sobrenatural. A própria Marie Taglioni esforçou-se para corresponder a essa imagem de feminilidade, procurando reforçar as características de uma mulher recatada, submissa, materna. Assim, procurou descolar-se das imagens que associavam dança e prostituição.

Embora as mulheres viessem para as luzes do palco e parecessem reinar com poder absoluto, o balé continuou sobre o domínio masculino, pois realmente quem tinha o controle atrás da cena eram os homens. Eles reinavam absolutos como professores de balé, coreógrafos, diretores, produtores, controlando e

SILVA, Daniela Grieco Nascimento e; FEIJÓ, Marcia Gonzalez. A construção do corpo doce da bailarina da caixinha de música. Revista da FUNDARTE. Montenegro, p.01-21, ano 20, nํ4, outubro/dezembro de 2020.

Disponível em: http://.seer.fundarte.rs.gov.br/index.php/revistadafundarte/index> 20 de dezembro de 2020. 


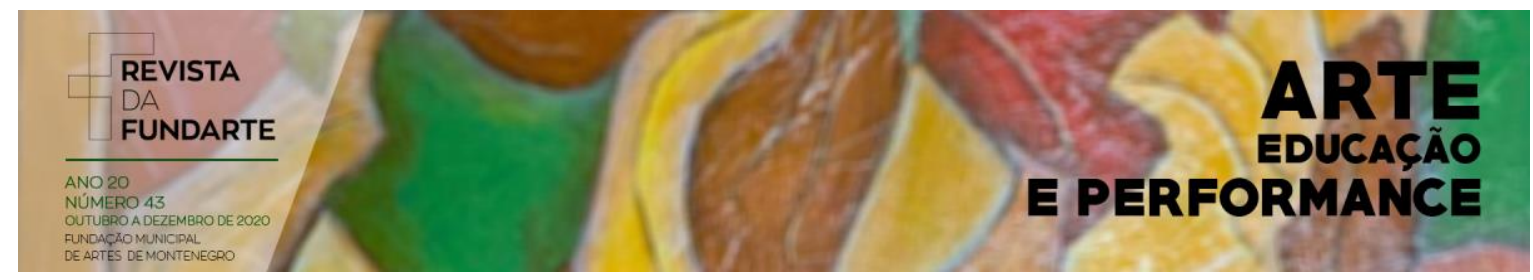

construindo as bailarinas segundo seus ideais. Um dos exemplos mais notórios é o pai de Marie Taglioni, que moldou a filha segundo seus princípios.

Ao enaltecer o eterno feminino no balé como um dos dispositivos de poder e de saber da arte, a mulher foi relegada a simples objeto. Por trás de todo 0 enaltecimento de sua figura, ela era prisioneira dos códigos morais e sociais impostos pela lei simbólica do patriarcado, que foi construída como poder, conjuntamente entre dominadores e dominados. Assim, ao sentir-se inferior, a mulher ignorava suas capacidades e era submetida ao domínio dos homens que, sem encontrar fortes resistências, propagavam suas concepções sobre a imagem feminina. Em vista de tal fato, as mulheres construíram sua imagem a partir dos ideais de feminilidade propostos pelo patriarcado, associando sua identidade e seu papel de gênero aos paradigmas hegemônicos de seu meio social e cultural, pois "a força da ordem masculina se evidencia no fato de que ela dispensa justificação: a visão androcêntrica impõe-se como neutra e não tem necessidade de se enunciar em discursos que visem a legitimá-la" (BOURDIEU, 2015, p.18)

Foi com a imagem de Marie Taglioni, reforçada pelos balés de repertório que se seguiram e que foram normalmente adaptados de contos de fadas, que começou a construção do corpo doce da bailarina clássica, criando a imagem feminina predominante no balé, que coloca a mulher como um ser de sonho e cria a imagem da bailarina da caixinha de música. Esta corresponde a uma figura feminina presa em uma caixa, condenada eternamente a repetir os mesmos movimentos de acordo com a mesma música, vendo sua imagem refletida em espelhos que reforçam sua prisão e calam sua voz.

SILVA, Daniela Grieco Nascimento e; FElJÓ, Marcia Gonzalez. A construção do corpo doce da bailarina da caixinha de música. Revista da FUNDARTE. Montenegro, p.01-21, ano 20, nํ4, outubro/dezembro de 2020.

Disponível em: http://.seer.fundarte.rs.gov.br/index.php/revistadafundarte/index> 20 de dezembro de 2020. 


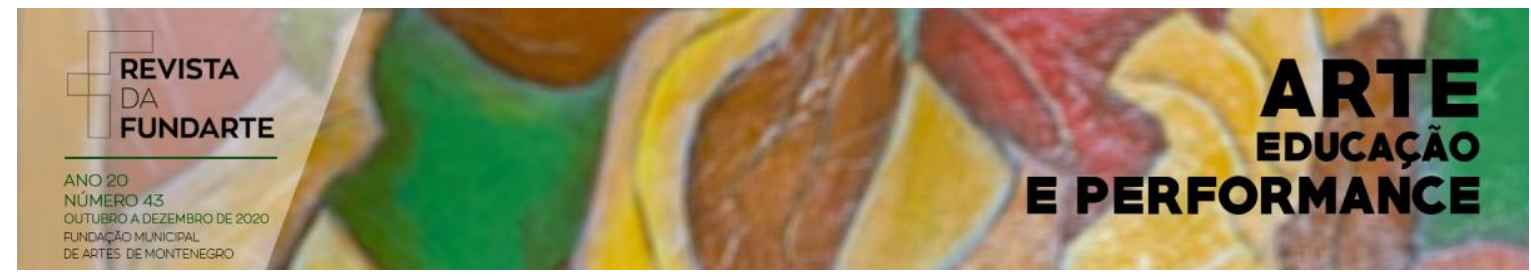

\section{Disciplinização dos corpos femininos: Construção do corpo doce da bailarina da caixinha de música}

Desde o reinado de Luís XIV, o balé tornou-se um meio de ascensão social na corte. Nobres disputavam a atenção e a estima do rei através do domínio da dança. Por conseguinte, o balé converteu-se em um dispositivo de poder, pois fez os sujeitos moldarem seus corpos segundo as vontades do soberano. Para Michel Foucault (2013), o poder se constitui em uma multiplicidade de forças que circulam no meio social, não possuindo um núcleo central. São essas forças móveis e maleáveis que compõem as relações entre sujeitos e classes, entre sujeitos e instituições. As instituições são lugares onde ocorrem intensificações das relações de poder, pois expressam o pensamento ideológico da classe dominante, que gera todas as conexões e jogos de poderes no meio social.

No momento em que o balé foi sistematizado e que foram fundadas instituições de ensino governamentais e particulares para desenvolver sua prática, ele tornou-se um dispositivo de poder, ligado aos interesses das classes dominantes, utilizando diversas táticas discursivas e práticas para alcançar seus objetivos. Tal como as escolas regulares, as escolas de balé centraram-se na tecnologia disciplinar para fabricar sujeitos por meio do adestramento, apropriandose dos corpos para torná-los instrumentos eficientes.

A disciplina utilizada pelas escolas de balé tradicionais modela os corpos individuais a fim de formar uma multiplicidade eficiente e produtiva, não reduzindo as forças do corpo, mas multiplicando-as até tornar o individual numa multiplicidade organizada. A disciplina no balé tem uma função normalizadora, estabelecendo uma prática pedagógica que ensina os códigos da dança e que também submete e ajusta o sujeito às leis sociais, culturais e políticas, que regem o meio social.

$\mathrm{Na}$ realidade, as disciplinas têm o seu discurso. Elas são criadoras de aparelhos de saber e de múltiplos domínios de conhecimento. São extraordinariamente inventivas no nível dos aparelhos que produzem saber e conhecimento. As disciplinas são portadoras de um discurso que não

SILVA, Daniela Grieco Nascimento e; FEIJÓ, Marcia Gonzalez. A construção do corpo doce da bailarina da caixinha de música. Revista da FUNDARTE. Montenegro, p.01-21, ano 20, no 43, outubro/dezembro de 2020.

Disponível em: http://.seer.fundarte.rs.gov.br/index.php/revistadafundarte/index> 20 de dezembro de 2020. 


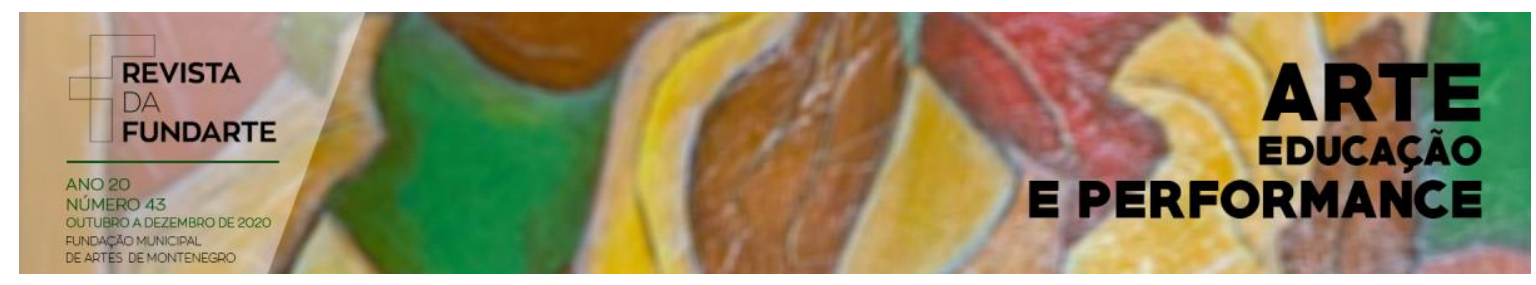

pode ser o do direito; o discurso da disciplina é alheio ao da lei e da regra enquanto efeito da vontade soberana. As disciplinas veicularão um discurso que será o da regra, não da regra jurídica derivada da soberania, mas da regra 'natural', quer dizer, da norma; definirão um código que não será o da lei, mas o da normalização; referir-se-ão a um horizonte teórico que não pode ser de maneira alguma o edifício do direito, mas o domínio das ciências humanas; a sua jurisprudência será a de um saber clínico. (FOUCAULT, 2013, p. 293).

Tal como na escola regular, a disciplina nas escolas de balé submeteu o corpo a uma forma de poder que irá desarticulá-lo e corrigi-lo, segundo uma nova mecânica do poder. As práticas disciplinares permitiram o controle das operações dos corpos e a sujeição constante de suas forças, impondo-lhes uma relação de docilidade e utilidade. Para tal, impôs algumas técnicas que colaboraram e contribuíram para a efetivação das disciplinas: distribuição dos sujeitos no espaço nas escolas de balé, os bailarinos são classificados segundo suas aptidões e desempenhos, avaliados, observados, recompensados - e controle da temporalidade - estabelecimento de horários rígidos de trabalho, sempre repetitivos e constantes, sem desperdício de tempo para o aprendizado da técnica da dança clássica.

A deferência ao mestre (proprietário de todo o saber) e as práticas constantes de exercícios são mais aproximações encontradas entre as escolas regulares e as escolas de balé, pois são os professores de dança (normalmente ex-dançarinos clássicos) que irão construir os corpos bailarinos, estabelecendo tradições e técnicas de movimentos. E é por meio dos exercícios nas aulas de balé que os corpos serão moldados, de acordo com a seriação e classificação dos bailarinos.

O ponto em apreço é o 'exercício', a técnica pela qual se impõe aos corpos, tarefas ao mesmo tempo repetitivas e diferentes, mas sempre graduadas. Dirigindo o comportamento para um estado terminal, o exercício permite uma perpétua caracterização do indivíduo, seja em relação a esse termo, seja em relação aos outros indivíduos, seja em relação a um tipo de percurso. Assim, realiza, na forma da continuidade e da coerção, um crescimento, uma observação, uma qualificação. (FOUCAULT, 2012, p. 155).

SILVA, Daniela Grieco Nascimento e; FEIJÓ, Marcia Gonzalez. A construção do corpo doce da bailarina da caixinha de música. Revista da FUNDARTE. Montenegro, p.01-21, ano 20, no 43, outubro/dezembro de 2020.

Disponível em: http://.seer.fundarte.rs.gov.br/index.php/revistadafundarte/index> 20 de dezembro de 2020. 


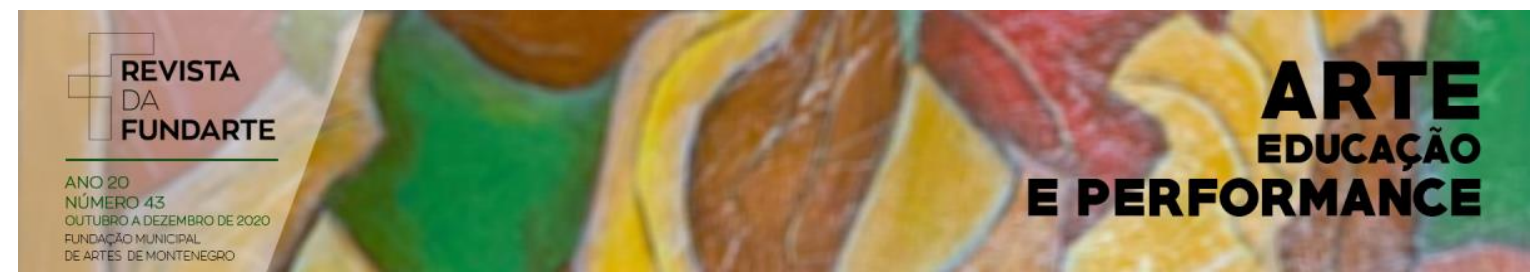

As práticas de exercícios irão moldar o corpo do bailarino e dirigir seu comportamento para um estado desejado, neste caso, estado de obediência e submissão ao mestre. Os exercícios irão visar, não apenas à coerção dos sujeitos, mas a sua qualificação para a prática do balé. Assim, os exercícios irão marcar a aquisição progressiva do saber na dança e a aquisição dos comportamentos desejados, segundo os códigos morais seguidos pela sociedade. Surgem os corpos dóceis (FOUCAULT, 2012), que são aqueles capazes de ser moldados, controlados, manipulados, submetidos pelo poder, fabricando o modelo de sujeito-bailarino que a sociedade deseja. O corpo dócil é então, significado, representado e interpretado culturalmente.

Um dos exemplos da construção dos corpos dóceis no balé, advém dos primórdios da Escola Russa, onde a formação dos bailarinos "seria caracterizada pela disciplina e arregimentação de estilo militar" (HOMANS, 2010, p. 285). Reverberando outras instituições disciplinares, o balé moldou corpos obedientes e deferentes, prontos a oferecer às respostas esperadas.

Como as mulheres predominam na prática do balé, seu corpo foi representado por meio das relações de poder, estabelecidas pela sociedade e pela cultura. Foi construído um corpo doce para a bailarina fabricado como o corpo dócil de Michel Foucault (2012), onde são inscritos os discursos hegemônicos masculinos em relação à feminilidade, criando o mito do eterno feminino.

As representações femininas do patriarcado são forças de poderes invisíveis e seus discursos incidem sobre o meio social, evidenciando sobre várias instituições (família, igreja, escola, estado), que auxiliarão na perpetuação da dominação masculina, reforçando atos e comportamentos femininos condizentes com a imagem de feminilidade desejada. No caso do balé, foi construída uma imagem da bailarina associada às mulheres do período romântico, onde a lei simbólica da dominação se inscreveu fortemente nos corpos e nas consciências femininas, criando a bailarina

SILVA, Daniela Grieco Nascimento e; FEIJÓ, Marcia Gonzalez. A construção do corpo doce da bailarina da caixinha de música. Revista da FUNDARTE. Montenegro, p.01-21, ano 20, no 43, outubro/dezembro de 2020.

Disponível em: http://.seer.fundarte.rs.gov.br/index.php/revistadafundarte/index> 20 de dezembro de 2020. 


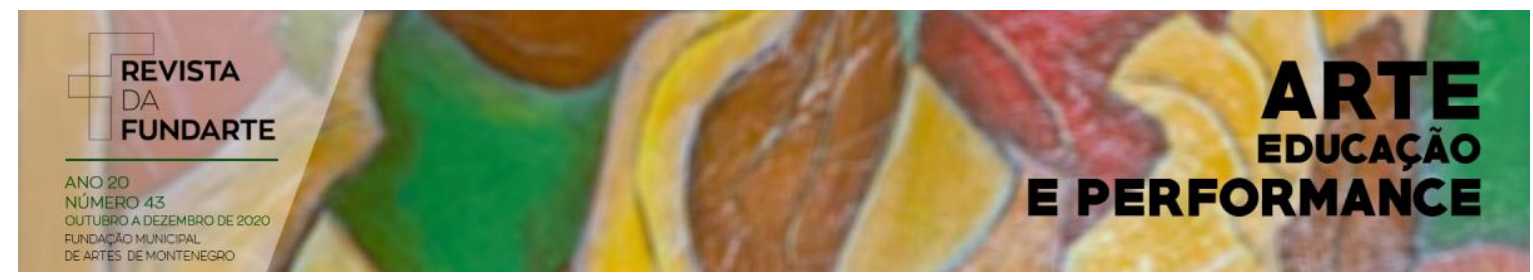

da caixinha de música. Segundo tal aspecto, uma menina pode ser auxiliada pela prática do balé a desenvolver atitudes e comportamentos considerados caracteristicamente femininos, sendo levadas pelas mães às escolas de dança como mais um aprendizado da feminilidade. As histórias dos balés de repertório (remontados pelas grandes companhias e pelas escolas de dança clássica) reforçam a associação com o mito do eterno feminino, pois incentivam imagens de heroínas puras, recatadas, belas e diáfanas que encontram amor e proteção na figura do "príncipe encantado".

A forte associação simbólica do balé com o universo feminino, aliada à baixa remuneração para os profissionais da dança, estabelecida após a Revolução Francesa, ocasionou que os homens que se tornaram bailarinos profissionais, depois dessa época na Europa e nos Estados Unidos fossem, conforme Judith Hanna (1999), cada vez mais homossexuais assumidos. Somente na Rússia, onde os bailarinos eram recrutados ainda meninos por meio de testes e custeados pelo governo, a heterossexualidade foi mais comum. Deste modo, é comum construir uma imagem do balé como uma arte essencialmente feminina, sexualizando a profissão da dança.

Outros fatores importantes na construção do corpo doce da bailarina da caixinha de música, são destacados por Judith Hanna (1999):

\begin{abstract}
Os coreógrafos e diretores do balé contemporâneo - quase sempre homens - moldam as moças do balé ao ideal de feminilidade que equipara a beleza e a graça à excessiva magreza, uma estética que é punitiva e misógina. As mulheres de seios ousados e quadris estreitos evocam a fantasia masculina de deflorar a virgem. A implacável perseguição do corpo feminino ideal e inatural detém a puberdade, desequilibra os hormônios, contribui para a hipotermia e baixa pressão sanguínea, levando frequentemente a problemas psicossomáticos de submissão à fome, de vômito e uso de laxantes, que estão relacionados com o mal [...] Os coreógrafos e os empresários tratam as bailarinas como crianças, educam-nas na obediência e na deferência, chamam as mulheres de "meninas" (e os homens de "meninos"). (HANNA, 1999, p. 191 -192).
\end{abstract}

SILVA, Daniela Grieco Nascimento e; FEIJÓ, Marcia Gonzalez. A construção do corpo doce da bailarina da caixinha de música. Revista da FUNDARTE. Montenegro, p.01-21, ano 20, no 43, outubro/dezembro de 2020.

Disponível em: http://.seer.fundarte.rs.gov.br/index.php/revistadafundarte/index> 20 de dezembro de 2020. 


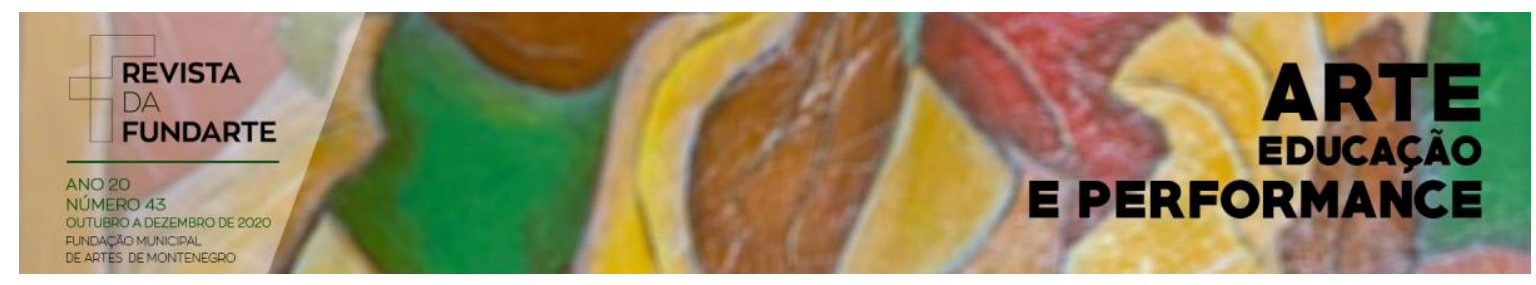

O padrão estético, estabelecido para o corpo doce da bailarina da caixinha de música, tortura penosamente este corpo, por meio de exercícios físicos fatigantes e por um padrão de beleza que, de certo modo, remete a um corpo infantil, que não desenvolve as formas de um corpo adulto. Tal infantilização da bailarina é um modo de dominação (as crianças devem obediência e submissão à figura paterna).

Judith Hanna (1999) salienta que George Balanchine atrelava o balé ao mito do eterno feminino, pontuando que este remetia permanentemente à mulher. Deste modo, a mulher era realçada em suas coreografias, devendo corresponder à imagem feminina idealizada por Balanchine que, tiranamente, moldava os corpos e as mentes das bailarinas, segundo seus princípios. Para Balanchine, as bailarinas deveriam ser magras e longilíenas, capazes de desafiar os limites de seus próprios corpos. Conta-se que Balanchine costumava tocar no dorso das bailarinas durante as aulas de balé, se sentisse suas costelas sem forçar, a bailarina estava em sua forma ideal.

Embora tenha sido um grande reformador do balé, ligando-o sobretudo à música e ao mundo contemporâneo, George Balanchine continuou atrelando a dança às redes de poderes que circulam pela sociedade patriarcal, reforçando a imagem do corpo doce da bailarina da caixinha de música.

A dominação masculina, que constitui as mulheres como objetos simbólicos, cujo ser (esse) é um ser-percebido (percipi), tem por efeito colocá-las em permanente estado de insegurança corporal, ou melhor, de dependência simbólica: elas existem, primeiro pelo e para o olhar dos outros, ou seja, enquanto objetos receptivos, atraentes, disponíveis. Delas se espera que sejam 'femininas', isto é, sorridentes, simpáticas, atenciosas, submissas, discretas, contidas ou até mesmo apagadas. E a pretensa 'feminilidade' muitas vezes não é mais que uma forma de aquiescência em relação às expectativas masculinas, reais ou supostas, principalmente, em termos de engrandecimento do ego. Em consequência, a dependência em relação aos outros (e não só aos homens) tende a tornar constitutiva de seu ser. (BOURDIEU, 2015, p. 82).

SILVA, Daniela Grieco Nascimento e; FEIJÓ, Marcia Gonzalez. A construção do corpo doce da bailarina da caixinha de música. Revista da FUNDARTE. Montenegro, p.01-21, ano 20, no 43, outubro/dezembro de 2020.

Disponível em: http://.seer.fundarte.rs.gov.br/index.php/revistadafundarte/index> 20 de dezembro de 2020. 


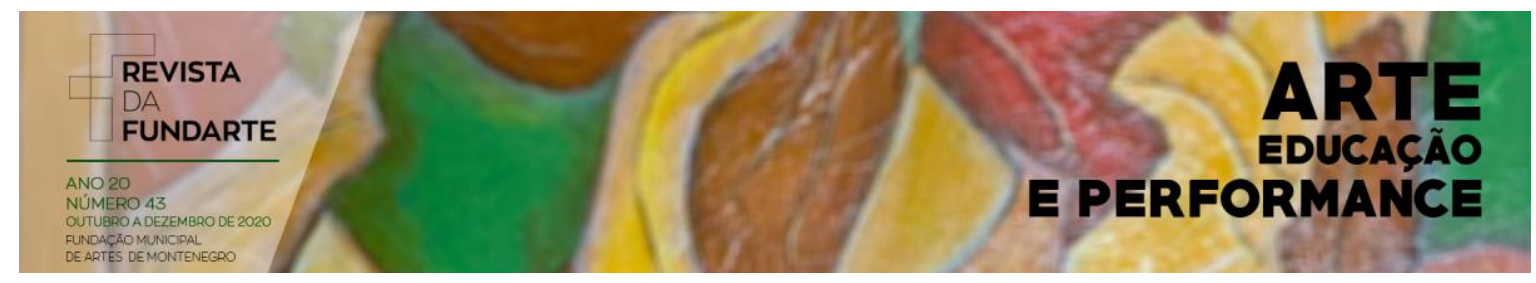

A construção do corpo doce da bailarina da caixinha de música é realizada de maneira sutil e quase imperceptível. As práticas rotineiras do balé carregam múltiplos discursos sobre os corpos femininos que acabam ressoando no meio social e cultural, instaurando saberes e produzindo verdades. Assim, as construções das imagens femininas estão sempre ligadas ao poder, sendo criadas dentro das próprias relações de poder. E é o discurso masculino que elege quais adjetivos e valores irão associar ao seu ideal feminino.

Considerando o discurso como uma forma de representação que dispõe de "uma função normativa e reguladora e estabelece mecanismos de organização do real, por meio da produção de saberes, estratégias e práticas” (REVEL, 2011, p. 41), a representação da bailarina clássica se perpetuou ao longo dos séculos, tendo um papel ativo na construção do corpo doce e na imagem da bailarina da caixinha de música. Foi tal representação que criou as bailarinas, dando significado ao ato de ser bailarina. Ou seja, se deseja tornar-se uma bailarina, a menina deve submeterse aos padrões estabelecidos pelo discurso que impera no mundo da dança, aceitando fazer de seu corpo um corpo doce, a fim de tornar-se mais uma bailarina da caixinha de música.

Cabe ressaltar que as figuras das bailarinas clássicas, ao povoarem 0 universo simbólico das meninas, constituem-se em seres sedutores e fascinantes, capazes de proezas corporais deslumbrantes e mágicas. E é por meio do mundo da imaginação e da fantasia, propagado pelo balé que se articula num poder cativante, mas que traz em seu cerne a repressão e a submissão dos corpos e das mentes das mulheres.

As escolas de balé, assim, são produtoras de identidades femininas no momento em que escrevem nos corpos das meninas marcas desta identidade, por meio do discurso, do olhar, da postura, dos gestos, das roupas. Toda disciplina imposta ao corpo doce da bailarina da caixinha de música tece redes simbólicas de

SILVA, Daniela Grieco Nascimento e; FElJÓ, Marcia Gonzalez. A construção do corpo doce da bailarina da caixinha de música. Revista da FUNDARTE. Montenegro, p.01-21, ano 20, nํ4, outubro/dezembro de 2020.

Disponível em: http://.seer.fundarte.rs.gov.br/index.php/revistadafundarte/index> 20 de dezembro de 2020. 


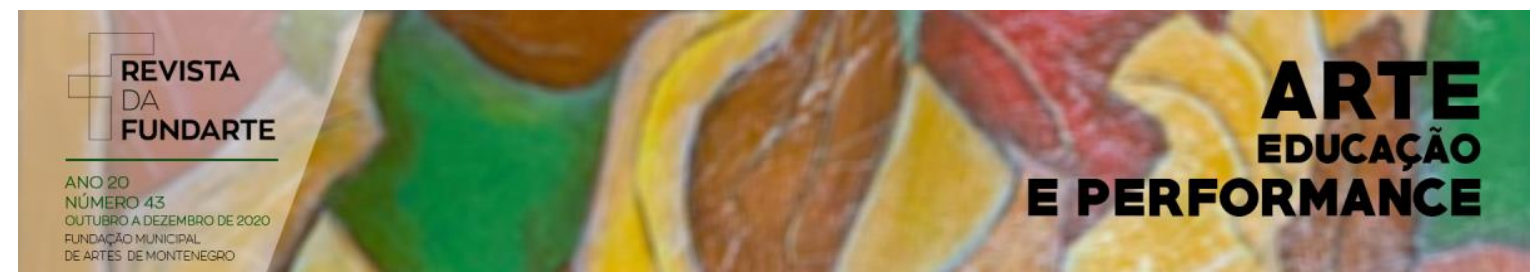

poderes e saberes que enredam o corpo, de maneira a impedir qualquer ato de resistência à hegemonia patriarcal.

É assim que as bailarinas, por meio de seus corpos doces adestrados e submissos, encantam ao corresponderem ao imaginário sonhado quando crianças. São as bailarinas da caixinha de música, apaixonadas por suas imagens e capazes de tudo para perpetuá-las, inclusive castigando o corpo por meio de anorexia, bulimia, cirurgias. São as bailarinas alienadas do mundo, que vivem e reproduzem apenas o imaginário do mundo do balé, dominadas e silenciadas pelo poder de coreógrafos, diretores e produtores. A bailarina da caixinha de música é a eterna menina do balé, que precisa ser cuidada, reverenciada e adorada.

Mas como todo o poder gera resistência, sempre se podem estabelecer rotas de fuga capazes de libertar a bailarina de sua caixinha de música, resinificando seu corpo e aproximando-a da realidade do mundo contemporâneo.

\section{Algumas Considerações}

Desde que Simone de Beauvoir lançou a obra "O Segundo Sexo" (1980a, 1980b), o protagonismo feminino adentrou em cena e iniciaram as lutas, a fim de garantir os direitos das mulheres. O movimento feminista trouxe outro olhar para a história das mulheres, concebendo uma nova ciência, que "se constitui no reverso da medalha, na outra leitura, na voz das que foram silenciadas" (LOURO, 2008, p. 148). Assim, os estudos feministas reconhecem todas as mulheres como sujeitos sociais e políticos, capazes de decidir seu futuro, empoderando-as como pessoas.

Cabe ressaltar que o termo empoderamento feminino significa conceder às mulheres o poder de participação social, política, econômica e cultural na sociedade, respeitando e garantindo seus direitos. O empoderamento feminino abarca duas dimensões: coletiva, que envolve maior participação das mulheres nos processos de decisões na sociedade, construindo políticas públicas que possam reverter as

SILVA, Daniela Grieco Nascimento e; FElJÓ, Marcia Gonzalez. A construção do corpo doce da bailarina da caixinha de música. Revista da FUNDARTE. Montenegro, p.01-21, ano 20, nํㄴ 43, outubro/dezembro de 2020.

Disponível em: http://.seer.fundarte.rs.gov.br/index.php/revistadafundarte/index> 20 de dezembro de 2020. 


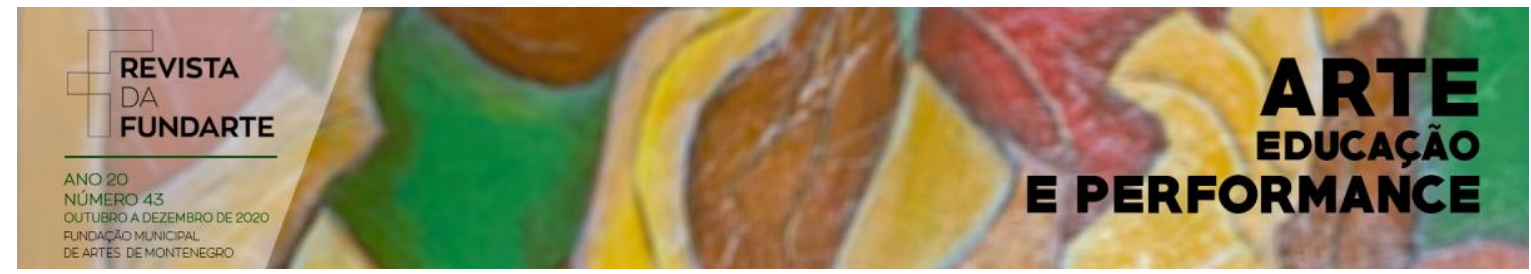

situações de opressão; e individual, que propicia às mulheres terem consciência de si mesmas como seres singulares, desenvolvendo sua autoestima e sua autonomia. As práticas do empoderamento feminino também são dirigidas aos homens para que todos possam trabalhar em prol da igualdade de gênero em todas as sociedades.

Novas formas de relações de poder e saber estão sendo tecidas e já começam a rachar velhos paradigmas em relação às mulheres. Espera-se a construção de outros caminhos que possibilitem maior igualdade entre os gêneros e que estes reflitam no mundo do balé, rompendo corpos doces e libertando bailarinas das caixinhas de música.

\section{Referências:}

BEAUVOIR, Simone. O segundo sexo: fatos e mitos. Rio de Janeiro: Nova Fronteira, 1980a.

Fronteira, 1980b.

O segundo sexo: a experiência vivida. Rio de Janeiro: Nova

BOURDIEU, Pierre. A dominação masculina. Rio de Janeiro: Bertrand Brasil Edições, 2015.

FOUCAULT, Michel. Em História da sexualidade 1: a vontade de saber. São Paulo: Paz e Terra, 2014.

. Microfísica do poder. São Paulo: Graal, 2013.

. Vigiar e punir: nascimento da prisão. Petrópolis: Vozes, 2012.

HANNA, Judith Lynne. Dança, sexo e gênero: signos de identidade, dominação, desafio e desejo. Rio de Janeiro: Rocco, 1999.

HOMANS, Jennifer. Os anjos de Apolo: uma história do ballet. Lisboa: Edições 70, 2010.

SILVA, Daniela Grieco Nascimento e; FEIJÓ, Marcia Gonzalez. A construção do corpo doce da bailarina da caixinha de música. Revista da FUNDARTE. Montenegro, p.01-21, ano 20, nํㄴ 43, outubro/dezembro de 2020.

Disponível em: http://.seer.fundarte.rs.gov.br/index.php/revistadafundarte/index> 20 de dezembro de 2020. 


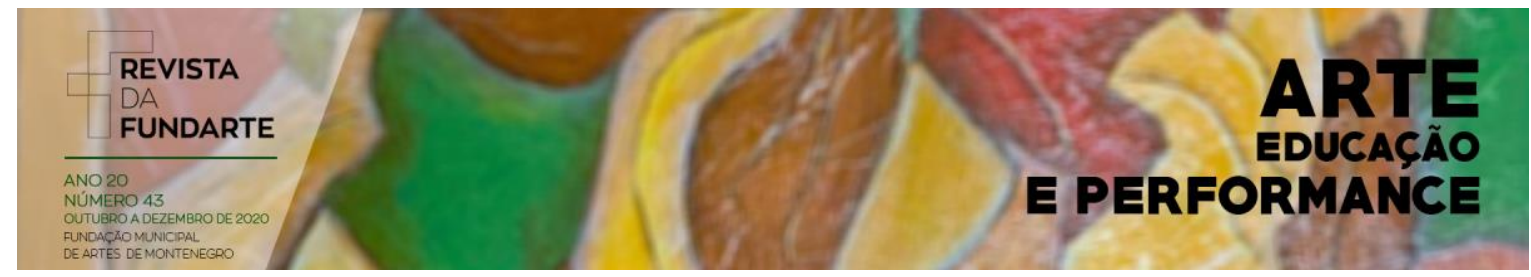

LOURO, Guacira Lopes. Gênero, sexualidade e educação: uma perspectiva pósestruturalista. Petrópolis: Vozes, 2008.

PERROT, Michelle. As mulheres ou os silêncios da história. Bauru: EDUSC, 2005.

REVEL, Judith. Dicionário de Foucault. Rio de Janeiro: Forense Universitária, 2011.

SILVA, Daniela Grieco Nascimento e; FEIJÓ, Marcia Gonzalez. A construção do corpo doce da bailarina da caixinha de música. Revista da FUNDARTE. Montenegro, p.01-21, ano 20, nํ4, outubro/dezembro de 2020.

Disponível em: http://.seer.fundarte.rs.gov.br/index.php/revistadafundarte/index> 20 de dezembro de 2020. 